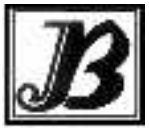

J. bio-sci. 21: 109-122, 2013

ISSN 1023-8654

http://www.banglajol.info/index.php/JBS/index

\title{
EVALUATION OF BARLEY GENOTYPES (HORDEUM VULGAR L.) BY DROUGHT TOLERANCE INDICES AND MULTIVARIATE ANALYSIS
}

\author{
Soran Sharafi ${ }^{*}$, Kazem Ghassemi-Golezani ${ }^{2}$, Soleyman Mohammadi ${ }^{3}$, Shahram Lak ${ }^{4}$, \\ Behzad Sorkhy ${ }^{5}$ \\ 1 Department of Agronomy and Plant Breeding, Science and Research Branch, Islamic Azad University, \\ Khouzestan, Iran \\ 2 Department of Agronomy and Plant Breeding, Faculty of Agriculture University of Tabriz, Iran \\ ${ }^{3}$ Agriculture and Natural Research Center of west Azerbaijan, Iran \\ 4 Department of Agronomy and Plant Breeding, Science and Research Branch, Islamic Azad University, \\ Khouzestan, Iran \\ 5 Seed and Plant Improvement Institute, Karaj, Iran
}

\begin{abstract}
Context: Evaluation of tolerance of different barley genotypes to drought stress, an experiment carried out in randomized block design (RCBD) with three replication during 2009-2010 growing seasons and 20 barley genotypes were studied in normal and water deficit in post anthesis stage conditions at the Saatloo Research Farm Azerbaiejan, Iran.

Results: The result of variance analysis showed that there were highly significant differences between genotypes in all of the studied traits, also it was cleared that all of traits except spike length reduced in water deficit condition as compared to normal condition and seed yield, biomass and 1000 seed weight traits had the most reduction (31, 25 and 20 percent, respectively). To identify of tolerance barley genotypes to drought stress, drought tolerance indices (STI, TOL, SSI, MP, HM and GMP), correlation coefficients, principal components analysis and cluster analysis were used. The result of correlation coefficients indicated that there were significant and positive correlation between seed yield in normal and stress conditions and drought tolerance indices. Also the result of principal components analysis showed that two components justified $99 \%$ of total variations. MP, GMP, STI and HM indices and TOL and SSI indices had the most coefficients in the first and second component, respectively, so are named tolerance and sensitivity component, respectively.

Conclusion: MP, HM, STI and GMP indices were appropriate indices to select of drought tolerance barley genotypes. On the other hand, the result of cluster analysis showed that 13, 14 and 7 genotypes and 18, 1 and 2 genotypes were tolerance and sensitivity genotypes to water deficit at post anthesis stage.
\end{abstract}

Key words: Barley, correlation coefficients, principal components analysis, cluster analysis, agronomical traits. Introduction

Barley is one of the most important cereal crops grown in many development countries, where it is often subject to extreme drought stress that significantly affects production (Ceccarelli et al. 2007). Drought stress is a multidimensional stress that effects on total green plant surface and plant response to drought stress are very intricate (Abarshahr et al. 2011, Araus et al. 2003). From the beginning of agriculture, drought is the main environmental constraint, causing famine and death in many parts of the world every year, often having devastating effects on crop productivity (Ilker et al. 2011, Khan and Naqvi 2011, Nazari and Pakniyat 2010, Kazmi et al. 2003, Lafitte et al. 2003, Pan et al. 2002). The effects of drought on yield of crops depend on

${ }^{\text {*C }}$ orresponding address E-mail: sharafi_1352@yahoo.com 
their severity and the stage of plant growth during which they occur (Rauf et al. 2007). Improve yield under drought is a major goal of plant breeding (Cattivelli et al. 2008). The best strategy for crop productivity, yield improvement, and yield stability under drought conditions is to develop drought-tolerant crop varieties (Cattivelli et al. 2008). Understanding the plant response in dry conditions has great importance and also a fundamental part of producing drought-tolerant cultivars (Zhao et al. 2008).

Selecting tolerant barley genotypes based on their yield performance under drought conditions is a common approach. Other approaches to identify tolerant genotypes to dry environment are drought tolerance indices. Several indices have been utilized to evaluate genotypes for drought tolerance based on grain yield in normal and stress environments (Talebi et al. 2009. Pireivatlou et al. 2010) and screen drought tolerant genotypes (Mitra 2001). The most important criteria such as Tolerance (TOL) (McCaig \& Clarke 1982, Clarke et al. 1992). Mean Productivity (MP) (McCaig \& Clarke 1982, Rosielle and Hamblin 1981), Stress Susceptibility Index (SSI) (Fischer \& Maurer 1978, Clark et al. 1992, Schneider et al. 1997), Geometric Mean Productivity (GMP) (Acosta-Gollegos and Adams 1991, Ramirez-Vallejo and Kelly 1998), Stress Tolerance Index (STI) (Fernandez 1992), Stress Intensity (SI) (Munns and James 2003), Yield Index (YI) (Gavuzi et al. 1997, Lin et al. 1986) and Yield Stability Index (YSI) (Bouslama \& Schapaugh 1984) have all been employed under various conditions. Sayyah et al. (2011) in their study on wheat genotypes reported that MP, GMP, STI indices were the most suitable drought tolerance criteria for screening substitution genotypes and when the stress was severe, SSI index was found to be more useful index in discriminating resistant genotypes. In the experiment of Khakwani et al. (2011), MP, GMP, STI, SSI and TOL indices are recognized as beneficial drought tolerance indicators for selecting a stress tolerant variety. Ilker et al. (2011) studied tolerance of indices on wheat genotypes and concluded that MP, GMP and STI values were convenient parameters to select high yielding wheat genotypes in both stress and non-stress conditions whereas RDY, TOL and SSI values were better indices to determine tolerance levels.

Since different barley genotypes have different responses to drought stress, this research has founded. The purpose of this study was the evaluation of drought stress influences on different barley genotypes and assessment of their tolerance and sensitivity to stress conditions and finally select the best suitable parents for hybridization in the breeding patterns.

\section{Materials and Methods}

\section{Experimental Design and Plant Material}

Twenty lines of winter barley (Hordeum vulgare L.) were chosen for investigation based on their reputed differences in yield performance under normal and drought stress conditions (the name of barley genotypes showed in Table 1). Two separate field experiments were conducted the 2007-2008 and 2008-2009 growing seasons at the Saatloo Research Farm (1338 m above sea level, 35N, 45E), West Azerbaijan, Iran. Saatloo has $375 \mathrm{~mm}$ annual rainfall on a long term average. The soil texture is clay-loom ( $30 \%$ clay, $53 \%$ silt and $17 \%$ sand) with $1.27 \%$ organic matter, a $\mathrm{pH}$ of 6.2 and $\mathrm{EC}$ of $2.5 \mathrm{dS} / \mathrm{m}$. The experiments were laid out as randomized complete block design (RCBD) with three replications. Control plots were watered at tillering, Joining, flowering and grain filling stages, but stress plots were watered at pre-flowering phases. Before planting, the soil surface was ploughed during autumn and then disked twice in September. Fertilizers were applied before sowing (100kg ha-1 P2O3 and 50kg ha-1 N) and at stem elongation (50kg ha-1 N). 
Table 1. Code and name of barley genotypes.

\begin{tabular}{|c|l|}
\hline Code & \\
\hline 1 & (EDB82-9)Rhn-03//L.527/NK1272 \\
\hline 2 & Manitou//Alanda/Zafraa \\
\hline 3 & Pamir-149/Victoria \\
\hline 4 & AcuarioT75/Azaf \\
\hline 5 & Pamir-146//EA389-3/EA475-4 \\
\hline 6 & Alpha/Durra/Pamir-160 \\
\hline 7 & Pamir-013/Sonata \\
\hline 8 & Robur/WA2196-68//Wysor \\
\hline 9 & Bugar/DZ48-232 \\
\hline 10 & Rhn-03//Lignee527/NK1272/5/Lignee527/Chn-01/4/Lignee527/ \\
\hline 11 & Mnitou//Alanda/Zafraa \\
\hline 12 & Kny/K-273 \\
\hline 13 & Pamir-065 \\
\hline 14 & Pamir-168 \\
\hline 15 & Prodcutiv/3/Rono//Alger/Ceres362-1-1 \\
\hline 16 & Belt67-1608/SIr/3/Dicktoo/Cascade//Hip/4/CWB117-77-9-7 \\
\hline 17 & Belt67-1608/SIr/3/Dicktoo/Cas \\
\hline 18 & U.Sask.1766/Api//Cel/3Weeah/4/Lignee527/NK1272/5/Express \\
\hline 19 & (EC82-6)TWWd85-37/Kavir \\
\hline 20 & (Bahman)WA196-68,F1//Scotia I \\
\hline
\end{tabular}

\section{Calculation of Drought Tolerance Indices}

Drought resistances were calculated using the following indices:

Table 2. Drought Tolerance Indices.

\begin{tabular}{|c|c|c|}
\hline Stress Tolerance Indices & equation & Reference \\
\hline Stress Susceptibility Index & $\left.s s r=\left(1-\frac{y^{\prime}}{r_{n}}\right)+\mathrm{i} 1-\frac{r}{Y_{n}}\right)$ & Fischer and Maurer (1978) \\
\hline Geometric Mean Productivity & 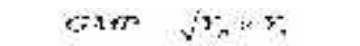 & Fernandes (1992) and Kristian et al. (1997) \\
\hline Mean Productivity & $w W-\frac{r_{m}+H_{n}}{2}$ & Rosielle and Hambling (1981) \\
\hline Harmonic Mean & $H_{H} w=\frac{-\left(r_{r} \times Y_{j}\right)}{\left(Y_{0}-Y_{i}\right)}$ & Jafari et al. (2009) \\
\hline Tolerance Index & 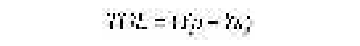 & Rosielle and Hambling (1981) \\
\hline Stress Tolerance Index & 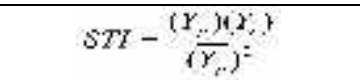 & Fernandes (1992) \\
\hline Reduction (\%) & $\frac{Y_{s} \quad r_{r}}{I_{1}} \geqslant 100$ & \\
\hline
\end{tabular}


Where Ys is the grain yield of genotype under drought stress, Yp the grain yield of genotype under nonstress, $\gamma \quad \bar{r}_{i}$

$$
\text { and the mean yields of all genotypes under stress and non-stress conditions, respectively, }
$$

and is the stress intensity.

\section{Statistical Analysis}

Analysis of variance, correlation among traits, correlation among indices and grain yield in two environments and Multivariate statistical analysis such as principle component analysis and cluster analysis were performed using SAS (SAS Institute 2002) and SPSS (version 21) software.

\section{Results and discussions \\ Agronomical traits}

The result of variance analysis of agronomical traits in normal and water deficit conditions demonstrated that there were high significant different between genotypes, years and genotypes $\times$ years (results do not shown). These results indicated that there were extremely genetic diversities between barley genotypes which can be used to select of appropriate genotypes for planting in any regains that exposed to water deficit at the end of vegetative stages, also genetic diversities between genotypes can be used in breeding programs and produced drought tolerance barley genotypes. On the other hand genotypes $\times$ year interaction was significant which shows that the genotypes responded differently to different treatments. Also results of Khakwani et al. (2011) experiment showed highly significant difference among wheat varieties in all the studied traits and water stress conditions decreased them significantly (Abarshahr et al. 2011).

The results of statistical parameters of agronomical traits in normal and water deficit conditions (Table 3) showed that all of agronomical traits except spike length reduced in water deficit condition as compared to normal condition. Seed yield (31\%), biomass (25\%) and 1000 seed weight traits $(20 \%)$ had the most reduction, respectively, whereas time of spike $(0 \%)$ and time of maturity traits $(6 \%)$ had the least reduction and spike length trait (-9\%) not only reduced but also increased in water deficit condition as compared to normal condition, so these traits introduced as resistant traits to water stress. These results coincide with the findings of Khan and Naqvi (2011), Zhou et al. (2007), Chandler and Singh (2008) and Bayoumi et al. (2008) who observed that drought caused reductions in all of agronomical traits. Oak et al. (2006) and Panthuwan et al. (2002) in rice and Pandey et al. (2001) in wheat expressed that grain yield, spike number, 1000 seed weight and plant height traits decreased in drought stress condition by $10 \%$ to $80 \%$, So, the overall effect of the drought stress depends on its intensity and length of stress (Bukhat 2005). On the other hand Johnson \& Kanemasu (1982) believed that under late season drought stress conditions, a fast decrease of current photosynthesis will be occurred which limits the translocation of assimilates into the grains.

Also the results of coefficient of variance (CV\%) in normal and water deficit conditions (Table 3) showed that seed yield, biomass and seed number of spike had the most diversity which can be used in breeding programs. Khakwani et al. (2011) stated that total grain yield per plant, biological yield per plant and harvest index were higher diversity in wheat varieties, which put they as a good candidate for selection criteria in wheat breeding program for drought resistance. 
Table 3. Statistical parameters of agronomical traits on Barley genotypes in normal and stress conditions.

\begin{tabular}{|c|c|c|c|c|c|c|c|c|c|c|c|}
\hline & Min & & Max & & Range & & $\begin{array}{c}\text { Average } \\
\pm \mathrm{SE}\end{array}$ & & & CV\% & \\
\hline & Normal & Stress & Normal & Stress & Normal & Stress & Normal & Stress & $\begin{array}{c}\text { Reduction } \\
\%\end{array}$ & Normal & Stress \\
\hline Yield & 4.5 & 2.51 & 5.64 & 4.25 & 1.14 & 1.74 & $\begin{array}{c}4.98 \pm \\
0.31\end{array}$ & $\begin{array}{c}3.42 \pm \\
0.46\end{array}$ & 31 & 12.59 & 14.29 \\
\hline $\begin{array}{l}\text { Harvest } \\
\text { Index }\end{array}$ & 32.07 & 29.22 & 45.53 & 39.63 & 13.46 & 10.41 & $\begin{array}{c}38.73 \pm \\
4.09\end{array}$ & $\begin{array}{c}34.28 \\
\pm 3 \\
\end{array}$ & 11 & 6.15 & 6.37 \\
\hline Biomass & 10.93 & 6.75 & 16.06 & 11.45 & 5.13 & 4.69 & $\begin{array}{c}12.94 \pm \\
1.63 \\
\end{array}$ & $\begin{array}{c}9.65 \pm \\
1.34 \\
\end{array}$ & 25 & 12.66 & 11.83 \\
\hline $\begin{array}{c}\text { Seed } \\
\text { Number } \\
\text { of Spike }\end{array}$ & 20.17 & 17 & 37.67 & 30.17 & 17.5 & 13.17 & $\begin{array}{c}27.63 \pm \\
5.6\end{array}$ & $\begin{array}{r}22.65 \\
\pm 3.68 \\
\end{array}$ & 18 & 10.55 & 11.62 \\
\hline $\begin{array}{c}1000 \\
\text { Seed } \\
\text { Weight }\end{array}$ & 30.06 & 23.94 & 49.93 & 43.47 & 19.88 & 19.53 & $\begin{array}{c}45.21 \pm \\
4.47\end{array}$ & $\begin{array}{c}36.07 \\
\pm 4.63\end{array}$ & 20 & 4.98 & 6.06 \\
\hline $\begin{array}{c}\text { Spike } \\
\text { Number }\end{array}$ & 48.67 & 45.67 & 83 & 73 & 34.33 & 27.33 & $\begin{array}{c}64.13 \pm \\
10.46 \\
\end{array}$ & $\begin{array}{l}57.04 \\
\pm 8.1 \\
\end{array}$ & 11 & 8.56 & 10.8 \\
\hline $\begin{array}{l}\text { Plant } \\
\text { Height }\end{array}$ & 61.65 & 47.8 & 82.96 & 71.6 & 21.31 & 23.8 & $\begin{array}{c}72.57 \pm \\
6.24 \\
\end{array}$ & $\begin{array}{r}61.67 \\
\pm 6.65 \\
\end{array}$ & 15 & 1.87 & 1.93 \\
\hline $\begin{array}{c}\text { Peduncle } \\
\text { Length }\end{array}$ & 18.27 & 18.74 & 31.72 & 26.29 & 13.45 & 7.56 & $\begin{array}{c}24.76 \pm \\
3.71\end{array}$ & $\begin{array}{r}22.29 \\
\pm 2.39 \\
\end{array}$ & 10 & 8.35 & 8.11 \\
\hline $\begin{array}{c}\text { Spike } \\
\text { Length }\end{array}$ & 3.81 & 4.64 & 6.72 & 7.57 & 2.91 & 2.93 & $\begin{array}{c}5.58 \pm \\
0.76\end{array}$ & $\begin{array}{c}6.11 \pm \\
0.75\end{array}$ & -9 & 9.24 & 9.23 \\
\hline $\begin{array}{l}\text { Time of } \\
\text { Spike }\end{array}$ & 120.17 & 120 & 129.67 & 130.33 & 9.5 & 10.33 & $\begin{array}{c}124.24 \pm \\
2.41\end{array}$ & $\begin{array}{l}123.74 \\
\pm 2.76\end{array}$ & 0 & 0.92 & 1.12 \\
\hline $\begin{array}{l}\text { Time of } \\
\text { Maturity }\end{array}$ & 165.67 & 155.17 & 180 & 170.67 & 14.33 & 15.5 & $\begin{array}{c}173.03 \pm \\
4.43\end{array}$ & $\begin{array}{r}163.4 \\
\pm 3.58\end{array}$ & 6 & 0.56 & 0.57 \\
\hline
\end{tabular}

The results of correlation coefficient between traits (Table 4) showed that there were positive and significant correlations between seed yield in normal and water deficit conditions with harvest index, biomass, number of spike, plant height and spike length traits, so if these traits improve, seed yield would improve, subsequently. Also it is cleared that genotypes had more height, there were more stored photosynthesis materials in their stems and had more 1000 seed weight, harvest index and seed yield, subsequently. So selection of higher genotype in drought stress will improve seed yield in barely genotypes. On the other hand, there were significant and negative correlations between seed yield at normal and water deficit conditions with spike length, time of spike and time of maturity traits. So the selection of precocious genotypes improve seed yield of barely genotypes and safe the plant from drought and high temperature stresses at the end of growth stage. Jongdee et al. (2006) have been reported that, in severe drought stress conditions, early flowering feature was a very important mechanism to escape from drought stress. Therefore, differences in flowering time among genotypes under these conditions can be used as stress tolerance index.

\section{Drought tolerance indices}

The results of variance analysis of drought tolerance indices and seed yield in normal and water deficit conditions (Table 5) showed that there were significant differences between genotypes, years and genotypes $x$ years. These results indicated that there are extremely diversity between barley genotypes from tolerance, resistance and sensitivity to water deficit stress. Also it enables us to select drought resistance genotypes to arid regions. Drikvand et al. (2012) in their study on wheat genotypes reported that there were highly significant differences among GMP, MP and STI and non-significant differences between SSI and TOL indices. This indicates the existence of genetic variation for the attributes studied and the possibility of 
selection for drought tolerance genotypes. The other researches such as Nazari and Pakniyat (2010) in barley genotypes reported high significant differences for all criteria.

Table 4. Correlation coefficients of agronomical traits on Barley genotypes in normal (below diagonal) and stress condition (above diagonal).

\begin{tabular}{|c|c|c|c|c|c|c|c|c|c|c|c|}
\hline Traits & $\begin{array}{c}\text { Yield } \\
\text { (1) }\end{array}$ & $\begin{array}{l}\text { Harvest } \\
\text { Index } \\
\text { (2) }\end{array}$ & $\begin{array}{l}\text { Biomass } \\
\text { (3) }\end{array}$ & $\begin{array}{c}\text { Seed } \\
\text { Number } \\
\text { of Spike } \\
(4)\end{array}$ & $\begin{array}{c}1000 \\
\text { Seed } \\
\text { Weight } \\
\text { (5) }\end{array}$ & $\begin{array}{c}\text { Spike } \\
\text { Number } \\
(6)\end{array}$ & $\begin{array}{c}\text { Plant } \\
\text { Height } \\
\text { (7) }\end{array}$ & $\begin{array}{l}\text { Peduncle } \\
\text { Length } \\
\text { (8) }\end{array}$ & $\begin{array}{l}\text { Spike } \\
\text { Length } \\
\text { (9) }\end{array}$ & $\begin{array}{c}\text { Time } \\
\text { of } \\
\text { Spike } \\
(10)\end{array}$ & $\begin{array}{c}\text { Time of } \\
\text { Maturity } \\
\text { (11) }\end{array}$ \\
\hline (1) & 1 & 0.58 ** & 0.64 ** & -0.24 * & 0.35 ** & 0.74 ** & 0.40 ** & 0.59 ** & $\underset{* *}{-0.50}$ & $\begin{array}{c}-0.39 \\
\star *\end{array}$ & -0.43 ** \\
\hline (2) & $\begin{array}{c}0.22 \\
*\end{array}$ & 1 & 0.03 & -0.03 & $0.29 * *$ & 0.64 ** & 0.25 ** & $0.53^{* *}$ & $\underset{* *}{-0.66}$ & $\begin{array}{c}-0.37 \\
\star \star\end{array}$ & -0.41 ** \\
\hline (3) & $\begin{array}{c}0.83 \\
*\end{array}$ & -0.32 ** & 1 & -0.38 ** & 0.32 ** & 0.42 ** & 0.28 * & 0.31 ** & -0.01 & $\begin{array}{c}-0.34 \\
\star *\end{array}$ & -0.28 ** \\
\hline (4) & 0.06 & 0.05 & -0.01 & 1 & -0.46 ** & -0.30 * & 0.05 & -0.16 & -0.05 & 0.17 & 0.22 * \\
\hline (5) & 0.05 & -0.13 & 0.13 & -0.31 ** & 1 & $0.47^{* *}$ & 0.03 & $0.30^{* *}$ & -0.19 * & $\underset{* \star}{-0.36}$ & -0.31 ** \\
\hline (6) & $\begin{array}{c}0.74 \\
*\end{array}$ & 0.14 & 0.63 ** & -0.1 & 0.05 & 1 & 0.26 ** & $0.59 * *$ & $\underset{* *}{-0.56}$ & $\begin{array}{c}-0.44 \\
\star \star\end{array}$ & -0.42 ** \\
\hline (7) & $\underset{* *}{0.57}$ & 0.22 * & 0.45 ** & -0.18 & 0.38 ** & 0.43 ** & 1 & 0.64 ** & -0.12 & $\underset{* *}{-0.37}$ & -0.11 \\
\hline (8) & $\begin{array}{c}0.42 \\
*\end{array}$ & 0.19 * & 0.31 ** & -0.09 & 0.33 ** & $0.29 * \star$ & 0.56 ** & 1 & $\underset{* *}{-0.52}$ & $\begin{array}{c}-0.43 \\
\star *\end{array}$ & -0.24 ** \\
\hline (9) & $\begin{array}{c}-0.50 \\
* *\end{array}$ & -0.42 ** & -0.26 ** & -0.32 ** & 0.30 ** & -0.38 ** & -0.17 & -0.06 & 1 & $\underset{* \star}{0.29}$ & $0.23^{\star}$ \\
\hline$(10)$ & $\begin{array}{c}-0.52 \\
\star *\end{array}$ & 0.04 & -0.53 ** & 0.18 & -0.29 ** & -0.57 * & $\underset{* \star}{-0.36}$ & -0.17 & 0.19 * & 1 & 0.36 ** \\
\hline (11) & $\begin{array}{c}-0.30 \\
\star *\end{array}$ & -0.08 & -0.26 ** & 0.07 & -0.11 & -0.41 ** & -0.09 & -0.13 & 0.22 * & $\underset{\star *}{0.41}$ & 1 \\
\hline
\end{tabular}

Table 5. Variance analysis of normal and stress yield and tolerance indexes on Barley genotypes.

\begin{tabular}{|c|c|c|c|c|c|c|c|c|c|}
\hline & & & & & & & & \\
\hline S.O.V & Df & Yp & Ys & TOL & MP & SSI & GMP & STI & HM \\
\hline Year & 1 & $\begin{array}{c}169.58 \\
\star *\end{array}$ & $78.04 * *$ & $17.56^{*}$ & $119.4 * *$ & 0.002 & $\begin{array}{c}112.25 \\
* *\end{array}$ & $0.65 * *$ & $\begin{array}{c}106.07 \\
* *\end{array}$ \\
\hline Error a & 4 & 0.33 & 1.12 & 1.53 & 0.34 & 0.13 & 0.44 & 0.003 & 0.56 \\
\hline Genotype & 19 & 0.59 & $1.27 * *$ & $1.31 *$ & $0.60 * *$ & $0.15 * *$ & $0.69 * *$ & $0.005^{* *}$ & $0.82 * *$ \\
\hline $\begin{array}{c}\text { Year } \\
\text { Genotype }\end{array}$ & 19 & $1.06 * *$ & $1.45^{* *}$ & $2.54 * *$ & $0.62 * *$ & $0.23 * *$ & $0.72 * *$ & $0.006 * *$ & $0.88^{* *}$ \\
\hline Error b & 76 & 0.39 & 0.24 & 0.61 & 0.16 & 0.05 & 0.16 & 0.001 & 0.17 \\
\hline Cv \% & --- & 12.59 & 14.29 & 15.24 & 9.61 & 18.23 & 9.72 & 19.32 & 10.3 \\
\hline & & & & & & & & & \\
\hline
\end{tabular}

The results of compare means of seed yield in normal and water deficit conditions and drought tolerance indices (Table 6) showed that seed yield in all of genotypes reduced in water deficit condition as compared to normal condition. But the procedure of reduction had different severities in barley genotypes, for example 1 and 2 genotypes had good yield in normal condition but their yield reduced in water deficit condition severity, whereas 13 and 3 genotypes had good yield in the both conditions, which indicated these varieties had 
stable performance, and produced a better yield under water deficit. The differential response of varieties to imposed water stress condition indicates the tolerance ability of barley varieties. These results are endorsed by Sayyah et al. (2011) who observed yields in the normal conditions were positively correlated with yields in the stress conditions.

Table 6. Means compares of normal and stress yield and tolerance indexes on Barley genotypes.

\begin{tabular}{|c|c|c|c|c|c|c|c|c|c|c|}
\hline Genotype Code & $Y p$ & Ys & TOL & MP & $\mathrm{SSI}$ & GMP & STI & $\mathrm{HM}$ & $\mathrm{TT}$ & Rank \\
\hline 1 & $5.06 \mathrm{a}$ & $2.78 \mathrm{bc}$ & $2.28 \mathrm{a}$ & $\begin{array}{l}3.92 \\
\text { abcd }\end{array}$ & $0.79 a b$ & $3.73 \mathrm{abc}$ & $0.13 \mathrm{bc}$ & $3.55 \mathrm{bcd}$ & 6.00 & 19 \\
\hline 2 & $4.67 \mathrm{a}$ & $2.51 \mathrm{c}$ & $2.15 \mathrm{a}$ & $\begin{array}{l}3.59 \\
\text { abcd }\end{array}$ & $0.84 \mathrm{a}$ & $3.41 \mathrm{c}$ & $0.11 \mathrm{c}$ & $3.24 \mathrm{~d}$ & 5.35 & 20 \\
\hline 3 & $4.78 \mathrm{a}$ & $3.85 a b$ & $0.93 a$ & $\begin{array}{l}4.32 \\
\text { abcd }\end{array}$ & $0.37 \mathrm{ab}$ & $4.28 \mathrm{abc}$ & $0.18 a b c$ & $4.25 a b c$ & 8.41 & 4 \\
\hline 4 & $4.94 \mathrm{a}$ & $3.14 a b c$ & $1.81 \mathrm{a}$ & $\begin{array}{l}4.04 \\
\text { abcd }\end{array}$ & $0.72 \mathrm{ab}$ & $3.92 \mathrm{abc}$ & $0.15 a b c$ & $\begin{array}{l}3.80 \\
\text { abcd }\end{array}$ & 6.77 & 16 \\
\hline 5 & $5.16 \mathrm{a}$ & $3.50 a b c$ & $1.66 \mathrm{a}$ & $\begin{array}{l}4.33 \\
\text { abcd }\end{array}$ & $0.57 a b$ & $4.24 a b c$ & $0.18 a b c$ & $\begin{array}{l}4.15 \\
\text { abcd }\end{array}$ & 7.69 & 10 \\
\hline 6 & $4.67 \mathrm{a}$ & $3.81 \mathrm{ab}$ & $0.86 \mathrm{a}$ & $\begin{array}{l}4.24 \\
a b c d\end{array}$ & $0.34 a b$ & $4.21 \mathrm{abc}$ & $0.16 a b c$ & $\begin{array}{l}4.18 \\
\text { abcd }\end{array}$ & 8.30 & 5 \\
\hline 7 & $5.64 \mathrm{a}$ & $3.90 \mathrm{ab}$ & $1.74 \mathrm{a}$ & $4.77 \mathrm{a}$ & $0.54 \mathrm{ab}$ & $4.68 \mathrm{a}$ & $0.21 \mathrm{ab}$ & $4.59 \mathrm{a}$ & 8.59 & 2 \\
\hline 8 & $4.51 \mathrm{a}$ & $2.96 \mathrm{bc}$ & $1.55 \mathrm{a}$ & $\begin{array}{l}3.73 \\
\text { abcd }\end{array}$ & $0.60 a b$ & $3.63 b c$ & $0.13 b c$ & $3.53 \mathrm{~cd}$ & 6.44 & 17 \\
\hline 9 & $5.08 \mathrm{a}$ & $3.75 \mathrm{ab}$ & $1.34 \mathrm{a}$ & $\begin{array}{l}4.42 \\
\text { abcd }\end{array}$ & $0.44 a b$ & $4.33 a b c$ & $0.18 a b c$ & $4.25 \mathrm{abc}$ & 8.19 & 7 \\
\hline 10 & $5.01 \mathrm{a}$ & $3.65 a b c$ & $1.36 \mathrm{a}$ & $\begin{array}{l}4.33 \\
\text { abcd }\end{array}$ & $0.47 \mathrm{ab}$ & $4.26 a b c$ & $0.17 a b c$ & $\begin{array}{l}4.19 \\
\text { abcd }\end{array}$ & 7.99 & 9 \\
\hline 11 & $4.67 \mathrm{a}$ & $3.80 \mathrm{ab}$ & $0.87 \mathrm{a}$ & $\begin{array}{l}4.24 \\
a b c d\end{array}$ & $0.38 a b$ & $4.20 \mathrm{abc}$ & $0.18 a b c$ & $\begin{array}{l}4.17 \\
\text { abcd }\end{array}$ & 8.26 & 6 \\
\hline 12 & $5.11 \mathrm{a}$ & $3.69 a b c$ & $1.42 \mathrm{a}$ & $\begin{array}{l}4.40 \\
\text { abcd }\end{array}$ & $0.48 a b$ & $4.33 a b c$ & $0.18 a b c$ & $4.26 \mathrm{abc}$ & 8.11 & 8 \\
\hline 13 & $4.94 \mathrm{a}$ & $4.25 \mathrm{a}$ & $0.70 \mathrm{a}$ & $4.60 a b c$ & $0.28 \mathrm{~b}$ & $4.57 \mathrm{ab}$ & $0.22 \mathrm{a}$ & $4.54 \mathrm{ab}$ & 9.22 & 1 \\
\hline 14 & $5.32 \mathrm{a}$ & $3.93 \mathrm{ab}$ & $1.39 \mathrm{a}$ & $4.63 a b$ & $0.55 a b$ & $4.53 \mathrm{ab}$ & $0.21 \mathrm{ab}$ & $4.43 \mathrm{abc}$ & 8.45 & 3 \\
\hline 15 & $5.54 \mathrm{a}$ & $3.30 a b c$ & $2.24 \mathrm{a}$ & $\begin{array}{l}4.42 \\
\text { abcd }\end{array}$ & $0.64 a b$ & $4.18 \mathrm{abc}$ & $0.16 a b c$ & $\begin{array}{l}3.98 \\
\text { abcd }\end{array}$ & 7.10 & 12 \\
\hline 16 & $4.86 \mathrm{a}$ & $3.14 a b c$ & $1.72 \mathrm{a}$ & $\begin{array}{l}4.00 \\
\text { abcd }\end{array}$ & $0.60 \mathrm{ab}$ & $3.89 \mathrm{abc}$ & $0.14 a b c$ & $\begin{array}{l}3.78 \\
\text { abcd }\end{array}$ & 6.87 & 14 \\
\hline 17 & $4.86 \mathrm{a}$ & $3.31 a b c$ & $1.55 \mathrm{a}$ & $\begin{array}{l}4.08 \\
\text { abcd }\end{array}$ & $0.64 a b$ & $3.98 \mathrm{abc}$ & $0.16 a b c$ & $\begin{array}{l}3.88 \\
a b c d\end{array}$ & 7.13 & 11 \\
\hline 18 & $4.50 \mathrm{a}$ & $2.80 \mathrm{bc}$ & $1.70 \mathrm{a}$ & $\begin{array}{l}3.65 \\
\text { abcd }\end{array}$ & $0.74 a b$ & $3.54 \mathrm{c}$ & $0.12 b c$ & $3.44 \mathrm{~cd}$ & 6.05 & 18 \\
\hline 19 & $5.31 \mathrm{a}$ & $3.13 a b c$ & $2.17 \mathrm{a}$ & $\begin{array}{l}4.22 \\
\mathrm{abcd}\end{array}$ & $0.68 \mathrm{ab}$ & $4.05 \mathrm{abc}$ & $0.16 a b c$ & $\begin{array}{l}3.90 \\
\mathrm{abcd}\end{array}$ & 6.88 & 15 \\
\hline 20 & $5.04 \mathrm{a}$ & $3.28 a b c$ & $1.76 \mathrm{a}$ & $\begin{array}{l}4.16 \\
\text { abcd }\end{array}$ & $0.67 \mathrm{ab}$ & $4.02 \mathrm{abc}$ & $0.15 a b c$ & $\begin{array}{l}3.89 \\
a b c d\end{array}$ & 7.04 & 13 \\
\hline
\end{tabular}


Among the stress tolerance indicators, a larger of TOL and SSI represent relatively more sensitivity to stress, thus a smaller value of TOL and SSI are favored to select of drought resistance genotypes. The lower these indices are, the more genotypes are drought resistance (Sio-Se Mardeh et al. 2006, Clarke et al. 1992). Several authors noticed that selection based on these two criteria favors genotypes with low yield potential under non stress conditions and yield under stress conditions (Golabadi et al. 2006, Zangi 2005, Fernandez 1992). In this study cleared that 13 genotype had the least value of TOL and SSI indices. It was more stable and showed high tolerance over water stress and introduced as resistant genotype. On the other hand 1 and 2 genotypes had the most value of TOL and SSI indices, so these genotypes are recommended as sensitivity genotypes. These results are in consistent with those reported by Zeinali et al. (2004), Sio- Se Mardeh (2006), Talebi (2009), Sanjari and Yazdansepas (2008), Nouri et al. (2011), Mohammadi et al. (2010), Karimizadeh and Mohammadi (2011) and Mohammadi et al. (2011). All of whom found these resistance indices to be suitable for discriminating the best genotypes under stress and irrigated conditions.

Since MP index calculates by the mean performance of seed yield at normal condition and seed yield at drought stress condition (Rosielle \& Hamblin 1981). So it is a sample and important index to select resistance and sensitivity genotypes. Seed yield of resistance genotypes have poor difference in normal and water deficit condition, so these genotypes have the higher MP value as compared to sensitivity genotypes. Fernandez (1992) believed that the selection on MP index redounded that genotypes with high potential yield are selected. In this study, 7 and 14 genotypes and 1 and 16 genotypes had the most and the least MP, so they are nominated resistance and sensitivity genotypes, respectively. Sio-Semardeh et al. (2006) reported that genotypes with relatively low yield exhibited high MP values under stress conditions. As described by Farshadfar and Sutka (2002), selection for MP increased yield in both stress and non-stress environments.

GMP and HM are geometric and harmonic means of seed yield in normal and water deficit conditions, respectively. So genotypes adjustments to drought stress and have high yield in normal and stress conditions, they have high geometric and harmonic means and nominated drought resistance genotypes (Abebe et al. 1998). In this study, 2 and 7 genotypes had the least and the most GMP and HM indices, so they are nominated sensitivity and resistance genotypes, respectively.

Study of drought effects on crops showed that seed yield of drought sensitivity genotypes reduce in drought stress condition, severely. So these genotypes have the least of STI value, whereas resistance genotypes have good yield in normal and stress conditions and their differences are very little. So these genotypes have the most of STI value. In totally, the STI index is used to select resistance and sensitivity genotypes in drought stress conditions (Fernandez 1992). In this study, 2 and 13 genotypes had the least and the most STI index, so they are nominated sensitivity and resistance genotypes, respectively. Pireivatlou et al. (2010) was also noted that STI can be a reliable index for selecting high yielding genotypes. In this regard, Moghaddam and Hadi-Zadeh (2002) found that STI was more useful index in order to select favorable cultivars under stressful and stress-free conditions.

In totally, genotypes have the least of SSI and TOL indices and the most of HM, MP, GMP, STI and SI are nominated drought resistance genotypes. So another index is identified that it is ranking genotypes on all of drought tolerance indices. This index is calculating on blow equation:

$$
\mathrm{TTI}=\mathrm{HM}+\mathrm{GMP}+\mathrm{STI}+\mathrm{MP}+\mathrm{SI}-\mathrm{SSI}-\mathrm{TOL}
$$


In this equation, the genotypes have higher value; they are resistant to drought stress. Inversely, the genotypes have lower value; they are sensitivity to drought stress. The results of this index are shown in Table 6. According this index, 13, 7 and 14 genotypes and 1, 2 and 18 genotypes had the most and the least value, so they are identified the resistance and sensitivity genotypes to drought stress, respectively.

To study of liner relationships between seed yield in normal and water deficient stress conditions and drought tolerance indices, correlation coefficients are calculated (Table 7). The results of correlation coefficients showed that seed yield in both conditions had positive and significant correlation with together. These results are confirmed with Karami et al. (2005), Farshadfar et al. (2001) and Golabadi et al. (2006), completely. Whereas, Feranandez (1992) in his research reported that the genotypes with good yield in normal condition may hadn't desirable yield in water deficient stress condition.

Table 7. Correlation coefficients of normal and stress yield and tolerance indexes on Barley genotypes.

\begin{tabular}{|c|c|c|c|c|c|c|c|c|}
\hline & & & & & & & & \\
\hline & $Y p$ & Ys & $\mathrm{TOL}$ & MP & SSI & GMP & STI & $\mathrm{HM}$ \\
\hline$Y p$ & 1 & 0.64 ** & 0.61 ** & 0.93 ** & 0.25 ** & 0.88 ** & 0.86 ** & 0.83 ** \\
\hline Ys & & 1 & -0.22 * & 0.88 * & -0.56 ** & 0.93 ** & 0.93 ** & 0.96 ** \\
\hline TOL & & & 1 & $0.27^{\text {** }}$ & 0.89 ** & 0.16 & 0.14 & 0.07 \\
\hline MP & & & & 1 & $-0.12^{\text {** }}$ & 0.99 ** & 0.98 ** & 0.98 ** \\
\hline SSI & & & & & 1 & -0.22 * & -0.23 * & -0.30 ** \\
\hline GMP & & & & & & 1 & 0.99 ** & 0.99 ** \\
\hline STI & & & & & & & 1 & 0.99 ** \\
\hline & & & & & & & & \\
\hline
\end{tabular}

On the other hand, it is cleared there were positive and significant correlations between seed yield in both conditions with GMP, MP, STI and HM indices. These results indicated that GMP, MP, STI and HM indices are very good criteria to select genotypes with high yield in normal and water deficient stress conditions. Therefore, it seems that selection planning based on these parameters can lead to determine tolerance barley is one of the most plausible strategies for better crop improvement under water deficient stress conditions. Blum (1996), Panthuwan et al. (2002) and Sio-Se Mardeh et al. (2006) believed that the effectiveness of selection indices depends on the stress severity supporting the idea that only under moderate stress condition, potential yield greatly influences yield under stress.

Nazari and Pakniyat (2010) showed the significant and positive correlation of Yp and Ys with MP, GMP and $\mathrm{STI}$, as well as, significant negative correlation of SSI and TOL. At last they revealed that selection for high values of MP, GMP and STI and low values of SSI and TOL could be useful. They also stated STI, MP and GMP are the best criteria for selection of high yielding genotypes both under stress and non-stress conditions. Drikvand et al. (2012) in wheat genotypes, Siose Marde et al. (2006), Golabadi et al. (2006) in durum wheat reported that GMP, MP and STI indices that were correlated with grain yield under both conditions, so they are suitable indices for screening wheat genotypes. Talebi et al. (2009) also reported that cultivars producing high yield in both drought and well watered conditions can be identified by STI, GMP and MP values.

\section{Multivariate analysis Principal analysis}

In order to further investigation on relationship among genotypes and stress tolerance indices, principal component analysis were performed (Table 8) that was reduced six indices down two components that they 
could overall justify about $99 \%$ of total variance. PCA revealed that the first component explained $74 \%$ of the total variation and the Yp, Ys, HM, MP, GMP and STI indices had the highest coefficients. Thus, the first dimension can be named as the yield potential and water deficient tolerance and these indices are the most important criteria to select favorite genotypes under normal and stress conditions. Talebi et al. (2009) also reported that cultivars producing high yield in both drought and well watered conditions can be identified by STI, GMP and MP values. These results coincide with the findings of Golabadi et al. (2006) in durum wheat, Farshadfar and Sutka (2002) in wheat. The second PCA explained 25\% of the total variation and SSI and TOL indices had the highest coefficients, so this component is named sensitive component. Fernandez (1992) believed that among the stress tolerance indicators, a larger of TOL and SSI represent relatively more sensitivity to stress, thus a smaller value of TOL and SSI are favored. Several authors noticed that selection based on these two indexes favors genotypes with low yield under non-stress conditions (Golabadi et al. 2006).

Table 8. Eigen value and vectors of principal component analysis for potential yield (YP), stress yield (YS) and stress tolerance indices.

\begin{tabular}{|c|c|c|c|c|c|c|c|c|c|c|}
\hline component & YP & YS & TOL & MP & SSI & GMP & STI & HM & $\begin{array}{c}\text { Cumulative } \\
\%\end{array}$ & Eigen value \\
\hline 1 & 0.92 & 0.66 & -0.04 & 0.94 & -0.34 & 0.88 & 0.84 & 0.82 & 76.4 & 4.4 \\
\hline 2 & -0.4 & 0.75 & -0.99 & 0.35 & -0.91 & 0.48 & 0.50 & 0.57 & 98.5 & 3.5 \\
\hline
\end{tabular}

According to the result of PCA, the selection of genotypes that have high PCA1 and low PCA2 are suitable for water deficient environments. Therefore in this study 13,14, 7 genotypes introduced as suitable and tolerant genotypes and 1, 2 and 18 genotypes introduced the most sensitive genotypes to orobanche weed stress. Drikvand et al. (2012) in their study on wheat genotypes reported that Principal component analysis reduced five indices down to two components with $99.49 \%$ proportional cumulative variance. Correlation and principal component analysis indicated that the most suitable criteria for the identification of genotypes under irrigated and rain fed conditions were GMP, MP and STI indices.

\section{Cluster analysis}

In order to classify of barley genotypes, cluster analysis on Wards Method is used. The result of cluster analysis on all of the drought tolerance indices (dendrogram 1) showed that studied barley genotypes classified in 4 classes. The numbers of genotypes in each class were 4, 6, 4 and 6 genotypes, respectively. The genotypes in each cluster evaluated together on agronomical traits and tolerant indices. Also the results of cluster analysis were compared to the ranking of genotypes in the Table 6 . At last it is confirmed that the results of cluster analysis on all of the tolerant indices were not accurate results. So the cluster analysis was performed on STI, MP, GMP and HM indices (the most important criteria that confirmed on correlation coefficients and principal component analysis, formerly). The results showed (dendrogram 2) that the tobacco genotypes classified in 4 classes. The numbers of genotypes in each class were 8, 5, 3 and 4 genotypes. These results were completely agreement to the ranking of genotypes in table 6 . The genotypes in each class evaluated on agronomical traits and tolerant indices. At last it is cleared that the genotypes in the first, second, third and fourth class were resistance, sensitive, very resistance and very sensitive genotypes, respectively. The other researchers such as Sayyah et al. (2011), Drikvand et al. (2012) and Azizinia et al. (2005) on wheat genotypes, Abarshahr et al. (2011) on rice genotypes, Farshadfar et al. (2001) on chickpea genotypes used cluster analysis for grouping genotypes on stress tolerance indices. 


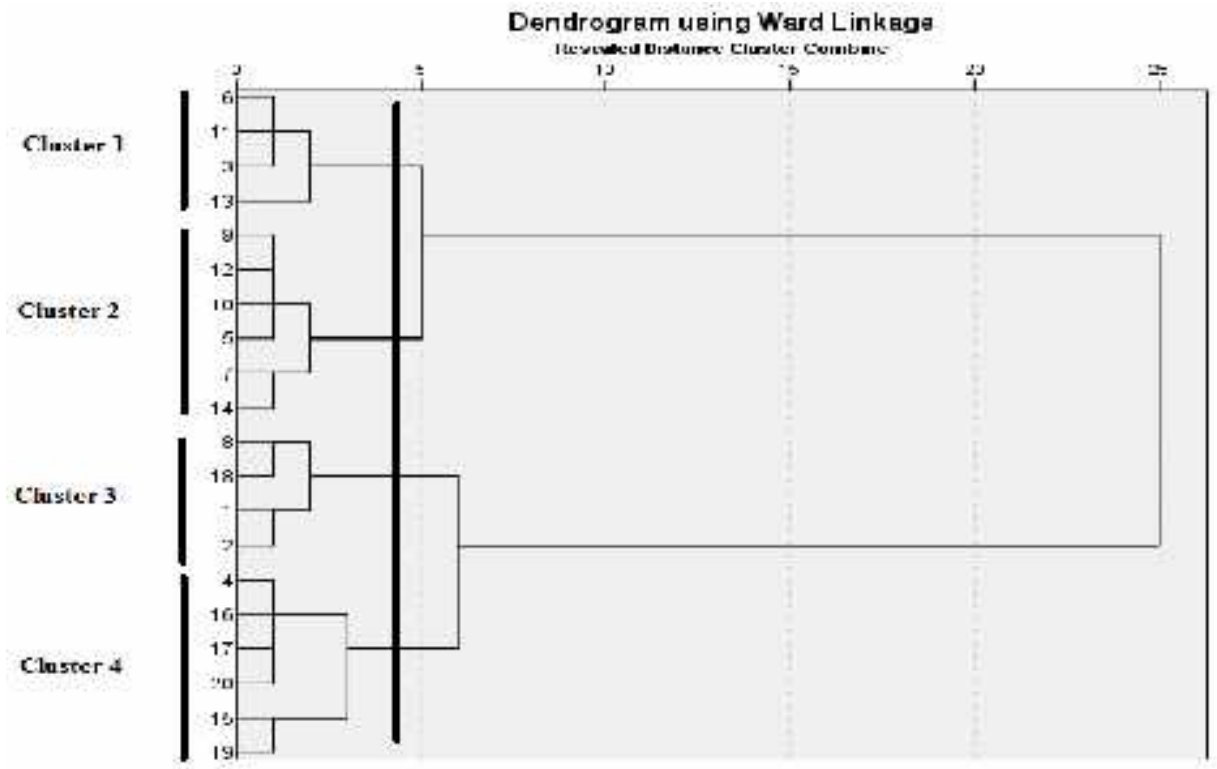

Finger 1- Dendrogram from cluster analysis based on stress tolerance indices and yield of barley genotypes in both normal and stress conditions.

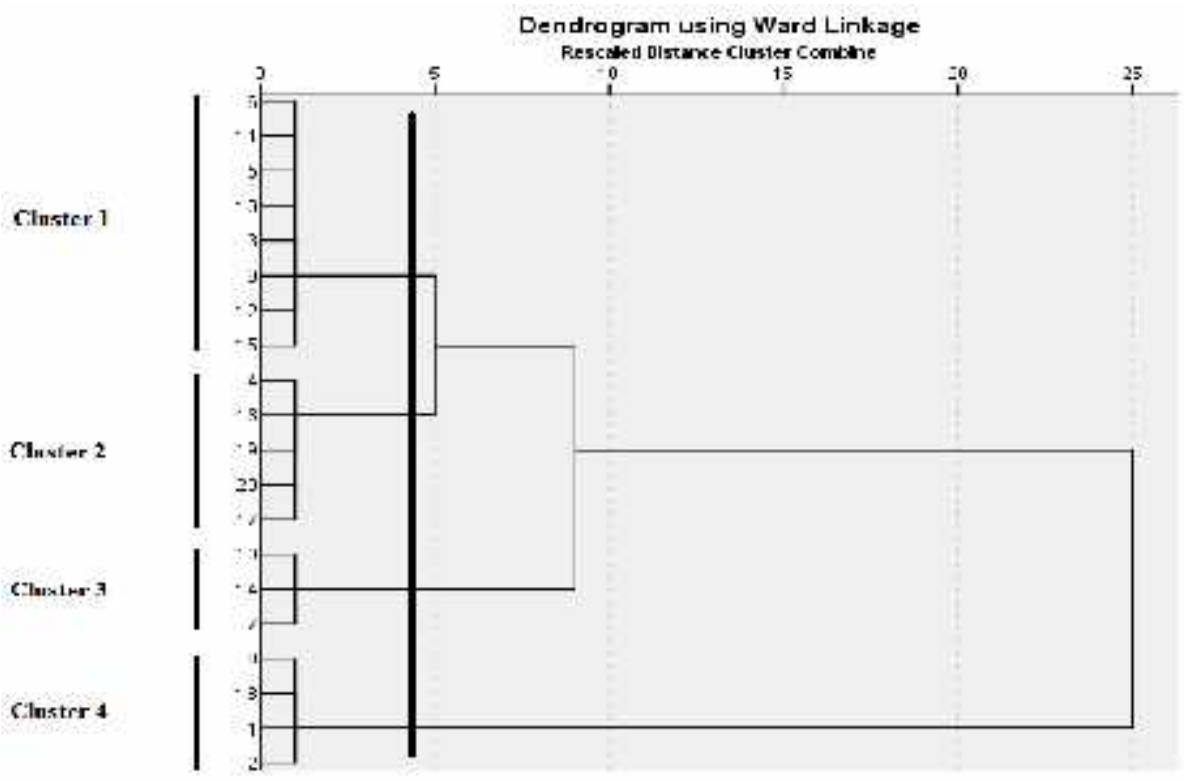

Finger 2- Dendrogram from cluster analysis based on HM, GMP, MP ant TOL indices and yield of barley genotypes in both normal and stress conditions. 


\section{Conclusion}

The results of the present study showed that there were high genetic differences between barley genotypes on agronomical traits and drought tolerance indices, so these genetic differences between barley genotypes can be used in breeding programs to product appropriate genotypes at normal and drought conditions. So in this study, it is confirmed that drought tolerance indices as efficiency criteria could be used to select drought resistant and sensitivity genotypes. Also the results of correlation coefficients and principal components analysis showed that GMP, MP, STI and HM indices were good criteria to select genotypes with high yield and drought resistance. Cluster analysis is used for classifying barley genotypes. Overall, in this study cleared that 7,13 and 14 identified as resistant genotype, so these genotypes recommended to normal and drought regions, but 1, 2 and 18 genotypes identified as sensitivity genotypes, so these genotypes only recommended to normal regions.

\section{References}

Abarshahr M, Rabiei B,Samizadeh Lahigi. H. 2011. Assessing Genetic Diversity of Rice Varieties under Drought Stress Conditions. Not Sci Biol 3(1), 114-123.

Abebe A, Brick MA, Kirkby RA. 1998. Comparison of selection indices to identify productive dry bean lines under diverse environmental conditions. Field Crops Res 58, 15-23. http://dx.doi.org/10.1016/S0378-4290(98)00082-3

Acosta-Gollegos JA, Adams MW. 1991. Plant traits and yield stability of dry bean (Phaseolus vulgaris) cultivars under drought stress. J Agric Sci Camb 117, 213-219. http://dx.doi.org/10.1017/S0021859600065308

Araus JL, Villegas D, Aparicio N, Garcia del Moral LF, El Hani S, Rharrabti Y, Ferrio JP, Royo C. 2003. Environmental factors determining carbon isotope discrimination and yield in drum wheat under Mediterranean conditions, Crop Science 43, 170-180.

http://dx.doi.org/10.2135/cropsci2003.1700, http://dx.doi.org/10.2135/cropsci2003.0170

Azizinia Sh, Ghanadha MR, Zali AA, Yazdisamadi B, Ahmadi A. 2005. Evaluation and assess of quantitative traits related to drought tolerance in wheat. Iran J Agric Sci 36, 281-292.

Bayoumi TY, Eid MH, Metwali EM. 2008. Application of physiological and biochemical indices as a screening technique for drought tolerance in wheat genotypes. African Journal of Biotechnology 7(14), 2341- 2352.

Blum A .1996. Crop responses of drought and the interpretation of adaptation. Plant Growth Regul 20,135-148. http://dx.doi.org/10.1007/BF00024010

Bouslama M, Schapaugh WT. 1984. Stress tolerance in soybean. I. Evaluation of three screening techniques for heat and drought tolerance. Crop Sci 24, 933-937. http://dx.doi.org/10.2135/cropsci1984.0011183X002400050026x

Bukhat NM, 2005. Studies in yield and yield associated traits of wheat (Triticum aestivum L.) genotypes under drought conditions. M.Sc. Thesis, Dissertation Submitted to Department of Agronomy, Sindh Agriculture University, Tandojam, Pakistan.

Cattivelli L, Rizza F, Badeck FW, Mazzucotelli E, Mastrangelo AM, Francia E, Mare C, Tondelli A, Stanca AM. 2008. Drought tolerance improvement in crop plants: An integrated view from breeding to genomics. Field Crop Res 105, 1-4. http://dx.doi.org/10.1016/j.frr.2007.07.004

Ceccarelli S, Grando S, Baum M. 2007. Participatory plant breeding in water limited environments. Exp Agric 43,1-25. http://dx.doi.org/10.1017/S0014479707005327

Chandler SS, Singh TK. 2008. Selection criteria for drought tolerance in spring wheat (Triticum aestivum L.). Series: Coping with wheat in a changing environment abiotic stresses. Proceedings of the 11th International Wheat Genetics Symposium. R. Appels, R. Eastwood, E. Lagudah, P. Langridge and M. Mackay Lynne, editors. Sydney University Press, Australia, pp. 1-3.

Clarke JM, De Pauw RM, Townley-Smith TM.1992. Evaluation of methods for quantification of drought tolerance in wheat. Crop Science 32, 728-732. http://dx.doi.org/10.2135/cropsci1992.0011183X003200030029x 
Drikvand R , Doosty B, Hosseinpour T. 2012. Response of Rain fed Wheat Genotypes to Drought Stress Using Drought Tolerance Indices. Journal of Agricultural Science 4(7), 126-131.

Farshadfar A, Zamani M, Matlabi M, Emamjome A. 2001. Selection for drought resistance in chickpea. Iran J Agric Sci $32,65-77$.

Farshadfar E, Sutka J. 2002. Multivariate analysis of drought tolerance in wheat substitution lines. Cereal Research Communications 31, 33-39.

Fernandez GCJ. 1992. Effective selection criteria for assessing plant stress tolerance. In: Kuo, C.G. (Ed.) Adaptation of Food Crops to Temperature and water stress. 257-269 pp.

Fischer RA, Maurer R. 1978. Drought resistance in spring wheat cultivars. I. Grain yield responses. Aust J Agric Res 29, 897-912. http://dx.doi.org/10.1071/AR9780897

Gavuzzi P, Rizza F, Palumbo M, Campaline RG, Ricciardi GL, Borghi B. 1997. Evaluation of field and laboratory predictors of drought and heat tolerance in winter and its components in wheat cultivars and landraces under near optimal and drought conditions. Euphytica 113, 43-52.

Golabadi M, Arzani A, Mirmohamadi Maibody SAM. 2006. Assessment of drought tolerance in segregating populations in durum wheat. Afric J Agric Res 1, 162-171.

Ilker E, Tatar Ö, Aykut Tonk F,Tosun M. 2011. Determination of tolerance level of some wheat genotypes to postanthesis drought. Turkish Journal of Field Crops 16(1), 59-63.

Johnson RC, Kanemasu ET. 1982. The influence of water availability on winter wheat yields. Canadian Journal of Plant Science 62, 831-838. http://dx.doi.org/10.4141/cjps82-125

Jongdee B, Pantuwan G, Fukai S, Fischer K (2006). Improving drought tolerance in rainfed lowland rice: an example from Thailand. Agricultural Water Management 80, 225-240. http://dx.doi.org/10.1016/j.agwat.2005.07.015

Karami E, Ghanadha MR, Naghavi MR, Mardi M. 2005. Identifying of drought tolerant varieties in barley. Iran J Agric Sci 37, 371-379.

Karimizadeh R, Mohammadi M. 2011. Association of canopy temperature depression with yield of durum wheat genotypes under supplementary irrigated and rainfed conditions. Aust J Crop Sci 5, 138-146.

Kazmi RH, Khan MQ, Abbasi MK. 2003. Effect of water stress on the performance of wheat grown under controlled conditions at Rawalakot, Azad Jammu and Kashmir. Sarhad J Agric 19, 61-67.

Khakwani AA, Dennett MD, Munir M. 2011. Drought tolerance screening of wheat varieties by inducing water stress conditions. Songklanakarin J Sci Technol 33 (2), 135-142

Khan N, Naqvi FN. 2011. Effect of Water Stress in Bread Wheat Hexaploids. Current Research Journal of Biological Sciences 3(5), 487-498.

Kristin AS, Serna RR, Pérez FI, Enríquez BC, Gallegos JAA, Vallejo PR, Wassimi N, Kelley JD.1997. Improving common bean performance under drought stress. Crop Sci 37, 43-50. http://dx.doi.org/10.2135/cropsci1997.0011183X003700010007x

Lafitte R, Blum A, Altin G. 2003. Using secondary traits to help identify drought tolerant genotypes. In: Fischer KS, Lafitte R, Fukai S, Altin G, Hardy B (eds.) Breeding rice for drought-prone environment. International Rice Research Institute. Los Banos, Philippines.

Lin CS, Binns MR, Lefkovitch LP. 1986. Stability analysis: where do we stand? Crop Science 26, 894-900. http://dx.doi.org/10.2135/cropsci1986.0011183X002600050012x

McCaig TN, Clarke JM.1982. Seasonal changes in nonstructural carbohydrate levels of wheat and oats grown in semiarid environment. Crop Science 22, 963-970. http://dx.doi.org/10.2135/cropsci1982.0011183X002200050016x

Mitra J. 2001. Genetics and genetic improvement of drought resistance in crop plants. Curr Sci 80, 758-762.

Mohammadi M, Karimizadeh R, Abdipour M. 2011. Evaluation of drought tolerance in bread wheat genotypes under dryland and supplemental irrigated conditions. Australian Journal of Crop Science 5, 487-493.

Mohammadi R, Armion M, Kahrizi D, Amri A. 2010. Efficiency of screening techniques for evaluating durum wheat genotypes under mild drought conditions. J Plant Prod 4, 11-24. 
Munns R, James RA. 2003. Screening methods for salinity tolerance: A case study with tetraploid wheat. Plant Soil 253, 201-218. http://dx.doi.org/10.1023/A:1024553303144

Nazari L, Pakniyat H. 2010. Assessment of drought tolerance in barley genotypes. Journal of Applied Sciences 10(2), 151-156. http://dx.doi.org/10.3923/jas.2010.151.156

Nouri A, Etminan A, Jaime A, Teixeira S, Mohammadi R. 2011. Assessment of yield, yield related traits and drought tolerance of durum wheat genotypes (Triticum turgidum var. durum Desf.). Aust J Crop Sci 5, 8-16.

Oak M, Basnayake J, Tsubo M, Fukai S, Fischer KS, Cooper M, Nesbitt H.2006. Use of drought response index for identification of drought tolerant genotypes in rainfed lowland rice. Field Crop Research 99(1),48-58. http://dx.doi.org/10.1016/j.fcr.2006.03.003

Pan XY, Wang YF, Wang GX, Cao QD,Wang J. 2002. Relationship between growth redundancy and size inequality in spring wheat populations mulched with clear plastic film. Acta Phytoecology Sinica 26, 177-184.

Pandey RK, Maronville JW, Admou A. 2001. Tropical wheat response to irrigation and nitrogen in a Sahelian environment. I. Grain yield, yield components and water use efficiency. Europ J Agron 15, 93-105. http://dx.doi.org/10.1016/S1161-0301(01)00098-3,

http://dx.doi.org/10.1016/S1161-0301(01)00097-1

Panthuwan G, Fokai S, Cooper M, Rajatasereekul S, Toole JCO. 2002. Yield response of rice genotypes to different types of drought under rainfed low lands. Grain yield and yield components. Field Crop Res 41, 45-54.

Pireivatlou AS, Masjedlou BD, Aliyev RT. 2010. Evaluation of yield potential and stress adaptive trait in wheat genotypes under post anthesis drought stress conditions, African Journal of Agricultural Research 5, 2829-2836.

Ramirez-Vallejo P, Kelly JD. 1998. Traits related to drought resistance in common bean. Euphytica 99, 127-136. http://dx.doi.org/10.1023/A:1018353200015

Rauf M, Munir M, Ul-Hassan M, Ahmed M, Afzai M. 2007. Performance of wheat genotypes under osmotic stress at germination and early seedling growth stage. African Journal of Biotechnology 8, 971-975.

Rosielle AA, Hamblin J. 1981. Theoretical aspects of selections for yield in stress and non-stress environments. Crop Sci 21, 943-946. http://dx.doi.org/10.2135/cropsci1981.0011183X002100060033x

Sanjari, PA, Yazdansepas A. 2008. Evaluation of wheat (Triticum aestivum L.) genotypes under preand post-anthesis drought stress conditions. J Agric Sci Tech 10, 109-121.

SAS Institute. (2002). SAS user's guide: Statistics version 9 for windows. SAS Institute., Carry, NC.

Sayyah SS, Ghobadi M, Mansoorifar S. Zebarjadi AR. 2011. Evaluation of Drought Tolerant in Some Wheat Genotypes to Post-anthesis Drought Stress. Journal of Agricultural Science 4(11), 248-256.

Schneider KA, Rosales-Serena R, Ibarra-perez F, Cacares-Enriguez B.. Acosta-Gallegos JA, Ramirec-Vallejo R, Wassimi N, Kelly JP. 1997. Improving common bean performance under drought stress. Crop Sci 37, 43-50. http://dx.doi.org/10.2135/cropsci1997.0011183X003700010007x

Sio-Se Mardeh A, Ahmadi A, Poustini K, Mohammadi V,2006. Evaluation of drought resistance indices under various environmental conditions. Field Crops Research 98(2-3), 222-229. http://dx.doi.org/10.1016/j.fcr.2006.02.001

SPSS. SPSS software for windows version 11.0. Inc., Chicago, IL.

Talebi R, Fayaz F, Naji AM. 2009. Effective selection criteria for assessing drought stress tolerance in drum wheat (Triticum durum Desf.) General and Applied Plant Physiology 35, 64-74.

Zangi MR.2005. Correlations between drought resistance indices and cotton yield in stress and non stress condition. Asian Journal of Plant Science 4, 106-108. http://dx.doi.org/10.3923/ajps.2005.106.108

Zeinali KH, Izanlo A, Hosseinzadeh A, Majnoun HN. 2004. Determine of appropriate drought resistance indices in imported soybean cultivars. Iran J Agric Sci 354, 875-885.

Zhao C, Guo LY, Jaleel CA, Shoa HB, Yang HB. 2008. Prospect for dissecting plant adaptive molecular mechanisms to improve wheat cultivars in drought environments. International Journal of Agriculture \& Biology 331, 579-586. 